\title{
Developing and assessing a virtual learning object with virtual simulation on zinc phosphate cement
}

Rodrigo Alves Tubelo*; Alessandra Dahmer**; Vicente Castelo Branco Leitune***; Maria Eugenia Bresolin Pinto****, Susana Maria Werner Samuel*****, Fabrício Mezzomo Collares***

* Doutorando em Odontologia, Programa de PósGraduação da Universidade Federal do Rio Grande do Sul.

** Doutora em Educação, Pontifícia Universidade Católica de São Paulo. Professora Adjunta da Universidade Federal de Ciências da Saúde de Porto Alegre

*** Professor Adjunto do Departamento de Odontologia Conservadora da Universidade Federal do Rio Grande do Sul.

**** $\quad$ Professora Adjunta da Universidade Federal de Ciências da Saúde de Porto Alegre

***** Professora Titular do Departamento de Odontologia Conservadora da Universidade Federal do Rio Grande do Sul.

\begin{abstract}
This study aimed to develop and assess a virtual learning object (VLO) on the subject of "luting agents", focusing especially on zinc phosphate cement (ZPC). The methodology and the necessary tools to develop the VLO are described. Dental students $(n=29)$ used this object for 15 days and completed a questionnaire in which they assessed it by using a 4-point scale. Developing the object allowed a virtual simulation of the manipulation of ZPC. The object received positive ratings from the students (4 points, $65.78 \%$; 3 points, $14.85 \%$ ). The software of choice enabled the combination of all media into one single VLO, which was widely accepted among dental students.
\end{abstract}

Descriptors: Dental Materials. Distance Education. Computer Simulation.

\section{INTRODUCTION}

The emergence of new information and communications technologies (ICTs) and the consolidation of the Internet have boosted changes in higher education ${ }^{1}$. The creation of free and open-source Virtual Learning Environments (VLE) lead to increased used of these platforms in universities and were effective and suitable for distance course environments. The Moodle platform (Modular Object-oriented Dynamic Learning Environment) being the one with the largest number of tools as compared to other learning environments ${ }^{2}$.

However, there is a need to improve the quality of digital content to these VLEs. Tools to create learning objects with the additional goal of introducing educational programs into these technologies were built with an interactive educational program that includes audios, videos, and animations. The VLO increase the learning process, making it easier for students to understand their content and thus increasing the level of user satisfaction ${ }^{3}$. 
The use of these objects with high-quality digital content in the learning process of Health Sciences students produced encouraging results $^{4,5}$, being effective learning tools in these distance courses ${ }^{6}$.

One of the interaction modalities explored by educators is virtual simulation, considered a widely accepted tool among health professionals ${ }^{7}$, providing an interface between the user and the computer which simulates an environment for the former ${ }^{8}$. Gamification techniques have been used to encourage students to take virtual simulation seriously. Supplementary elements, such as challenges and rewards, are some of these techniques, which are also seen in videogames. This kind of simulation is based on a studentcentered approach, in which students interact with both the educational object and the available content.

VLOs that simulate clinical cases have been approved by dental students and teachers ${ }^{10}$. Aside from user approval, the process of describing the development of simulators is of major importance in that it will enable other groups of Dentistry students to use these tools from different perspectives ${ }^{11}$. Thus, the aim of this study is to develop and assess a VLO designed for dental undergraduates, which focuses on luting agents, especially on zinc phosphate cement (ZPC).

\section{METHODS}

\section{Study Design}

Forty-six dentistry undergraduates enrolled in the Dental Materials course were assigned to use the VLO. This study is registered at Plataforma Brasil (CAAE: 37347214.6.0000.5347). The VLO was developed by the Dental Materials Laboratory of the Universidade Federal do Rio Grande do Sul (UFRGS) together with the
Universidade Aberta do Sistema Único de Saúde (UNA-SUS) at the Universidade Federal de Ciências da Saúde de Porto Alegre (UFCSPA). The development stage had the following steps.

\section{Course Planning}

Aspects such as target audience, credit hours, syllabus, and general and specific objectives were all taken into consideration when developing the course plan. Furthermore, the VLO program was described in detail, and the following topics were discussed: dental cements and their practical use, general requirements for using them, retention mechanisms, and mechanical and physical properties. The focus was on ZPC, and the content of this topic included the following items: presentation and history, composition and setting reaction, biocompatibility, solubility, viscosity, working and setting time, placement, mixing, and manipulation. Additionally, a storyline, physical infrastructures, and assessment criteria were included. The course plan was revised and approved by the teacher responsible for the course.

\section{Layout Design}

Two software programs were used in the layout design: Adobe Photoshop CS6 (Adobe Systems, Inc., San Jose, California, USA) and Articulate Storyline 2 (Articulate Global, Inc., New York, NY, USA). The former is an image editor and creator which was used to render icons, logos, and pictures based on a scientific article ${ }^{14}$ and on books ${ }^{12,13}$. As for Articulate Storyline 2, it is an authoring software, which is used to produce digital educational objects in which all of the contents of the learning object (videos, voice-over, images, animations, and simulations) are combined in one single file. 


\section{Organization of Content}

Concerning the production of digital educational materials, a storyboard was developed based on the course plan. This storyboard contained all of the necessary information to organize content in a VLO.

\section{Video Production}

A video showing ZPC being mixed properly was developed to design the VLO. This video was adapted from a script based on books and on the instructions manual provided by the manufacturer (Vigodent S/A, Rio de Janeiro, RJ, Brazil). Moreover, a professor with knowledge in the specific area revised the text.

A lightbox (size: $28 \times 20 \times 20$ inches) was made to record videos and capture images. Three 500-watts incandescent light bulbs provided lighting. Two of them were placed on the sides, and the other one was placed on top of the lightbox.

Audio recording took place in a quiet room, and the sounds were taped with a Moto $\mathrm{G}$ built-in microphone (Motorola Mobility LLC, Libertyville, IL, USA). Videos were recorded with a Nikon 3200 camera (Nikon do Brasil Ltda., Manaus, AM, Brazil). A professor of the Dental Materials course handled the material during video production.

Once audio recording, video shooting, and image capture were finished, the video was edited with image editor Sony Vegas Pro 13 (Sony Creative Software, Inc., California, USA), and so the images and videos produced were synchronized with the audio.

\section{Designing the Virtual Learning Object}

Computer software Articulate Storyline 2 was used to combine all of the media developed and to organize their content digitally. This allowed the material provided by the storyboard to be inserted in an online platform.

\section{Virtual Simulation}

Students assessed the mixing of ZPC with the help from a virtual simulator developed with Articulate. They were shown images of a glass slab and a spatula and were supposed to add powder to the liquid and mix it vigorously all over the glass slab area. The faster the mixing, the more points the "powder incorporation" item would be given. The larger the area used during mixing, the more points the "use of the glass slab area" would be given. Figure 1 illustrates the beginning of the simulation. Furthermore, there was a time progress bar of each increment. At the end of the time of each increment, students were sent some feedback on manipulation up until that moment. This included information on the two variables (use of the glass slab area and power incorporation), so students were given the options to incorporate the next increment or restart manipulation. At the end of the simulation of, participants were sent final feedback containing the following information: powder mixing mean (0-100\%), use of the glass slab area mean (0-100\%), and their final grade, which was calculated based on the two aforementioned means. Students could either "submit grade" or "restart manipulation" by clicking on one of the buttons on the side.

\section{Interaction with the Virtual Learning Environment (VLE)}

Information gathered by Articulate software had to be transferred to the Moodle 2.6 VLE, and to do so, an answer screen was added to the task. This screen collected results from the tasks (true or false, multiple choice, drag and drop, quiz, among others) developed with Articulate. This way, this information could be converted and sent to the Moodle 
platform. Even though Articulate was not developed to produce virtual simulations, its "create variables" tool can be used to store information regarding how much of the glass slab area was used and how much powder was mixed.

Thus, these variables were stored to send the simulation results to Moodle.

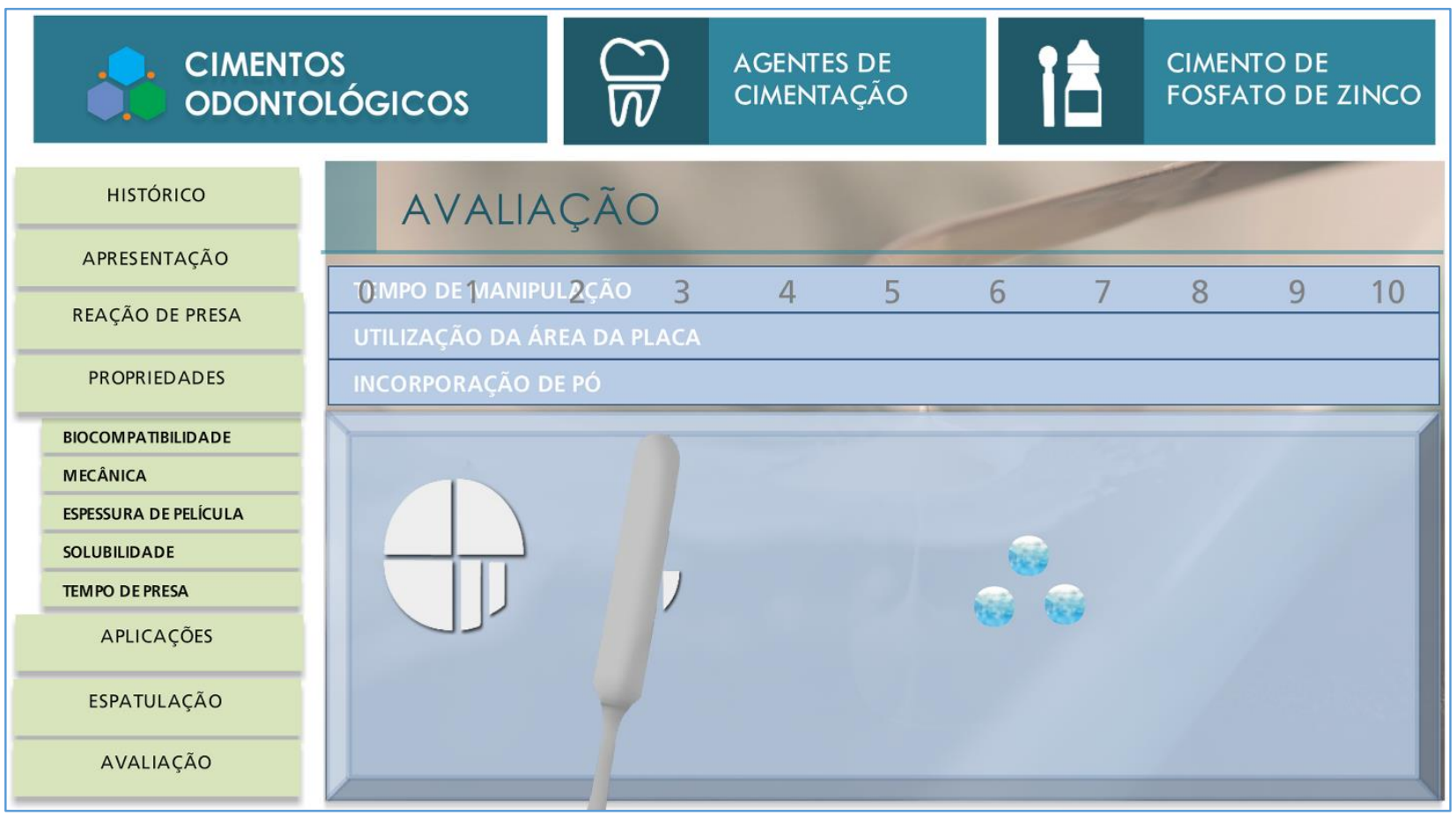

Figure 1 - Screen capture of the VLO as the virtual simulation of ZPC being mixed begins.

\section{Assessment Questionnaire of the Object}

An assessment questionnaire was designed to assess the VLO. It was comprised of 13 questions (based on the Guidelines for Virtual Object Assessment ${ }^{15}$ ) related to the educational and technical aspects of the object. In order to make it easier to analyze the answers, the questionnaire was divided into sections according to the content of each question (Figure 2). Alternatives were defined according the Likert scale, ranging from 0 to 4 ( 0 = never; 4 = always).

Participants finished using the VLE and a week later, attended a class to complete the assessment questionnaire.

\section{RESULTS}

Designing the course plan was of great help in the educational guidance for which the VLO was developed by outlining the subject covered and by illustrating the syllabus and other goals, which should be reached on the ZPC distance course. It has been observed that designing a layout based on the course plan allowed proper arrangement of buttons and menus, making users aware of content distribution.

Producing and inserting a video depicting the manipulation of ZPC was useful to the VLO because this was a graphical and practical way to inform students on the 


\begin{tabular}{|c|c|c|}
\hline 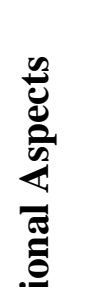 & 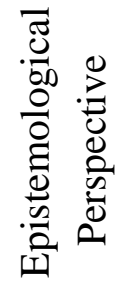 & $\begin{array}{l}\text { 1. Does the object give information in short sections? } \\
2 . \quad \text { Does it encourage you to search for other information in different } \\
\text { sources? } \\
\text { 3. Does it promote discussion with other students and the teacher } \\
\text { through forums on the topics covered? }\end{array}$ \\
\hline$\underset{\mathrm{J}}{\underline{\mathrm{J}}}$ & 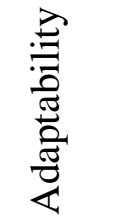 & $\begin{array}{l}\text { 4. Is information offered through different media, such as readings, } \\
\text { animations, and videos? }\end{array}$ \\
\hline & 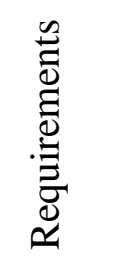 & $\begin{array}{l}\text { 5. Is information offered through different media, such as readings, } \\
\text { animations, and videos? } \\
6 \text {. Is the processing speed compromised when you use the object on } \\
\text { your computer? }\end{array}$ \\
\hline 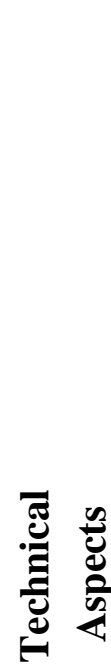 & 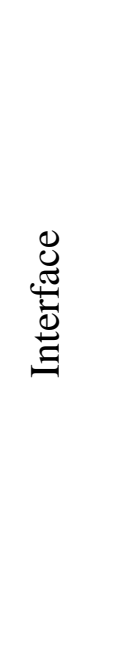 & $\begin{array}{l}\text { 7. Are the images just for show or are they actually used to illustrate } \\
\text { concepts and explanations? } \\
8 \text {. Is the font size appropriate? } \\
9 \text {. Is there visual consistency in how information (titles, typesetting, } \\
\text { text arrangement, graphical tools) is presented? } \\
\text { 10. Can you rely on the menu and the titles to determine where you } \\
\text { are with the learning object at any time? } \\
\text { 11. Are the icons, which give access to other pages and functions of } \\
\text { the object easily understandable? } \\
\text { 12. Are there any interactive tools? } \\
\text { 13. Does the learning object have graphical tools, which enhance the } \\
\text { interface's aesthetic aspect? }\end{array}$ \\
\hline
\end{tabular}

Figure 2 - Distribution of the questionnaire items according to the subject covered.

importance of manipulating ZPC and on the influence this manipulation has on the properties of the dental cement. The use of an authoring software such as Articulate allowed the combination of different media into one single VLO. This object can be exported to two formats: LMS (Learning Management System), used in VLEs, and HTML5, widely used in web browsers.
The variable tool was used to create the virtual simulation of the manipulation of ZPC, which allowed the use of gamification techniques in e-learning. These include a feedback system with both positive and negative remarks, a timer, points to each increment added, a final grade and its storage on the Moodle VLE (http://www.ufrgs.br/ lamad/fosfato-de-zinco/fosfato-de-zinco/view). 
Overall, the VLO received positive ratings in both educational and technical matters. $65.78 \%$ of the questions were given 4 points (always), $14.85 \%$ were given 3 points (usually), $13 \%$ were given 2 points (rarely), and $2.39 \%$ were given 0 points (never). Distribution can be found in Figure 3. Cronbach's alpha coefficient of the questionnaire was 0.57 .

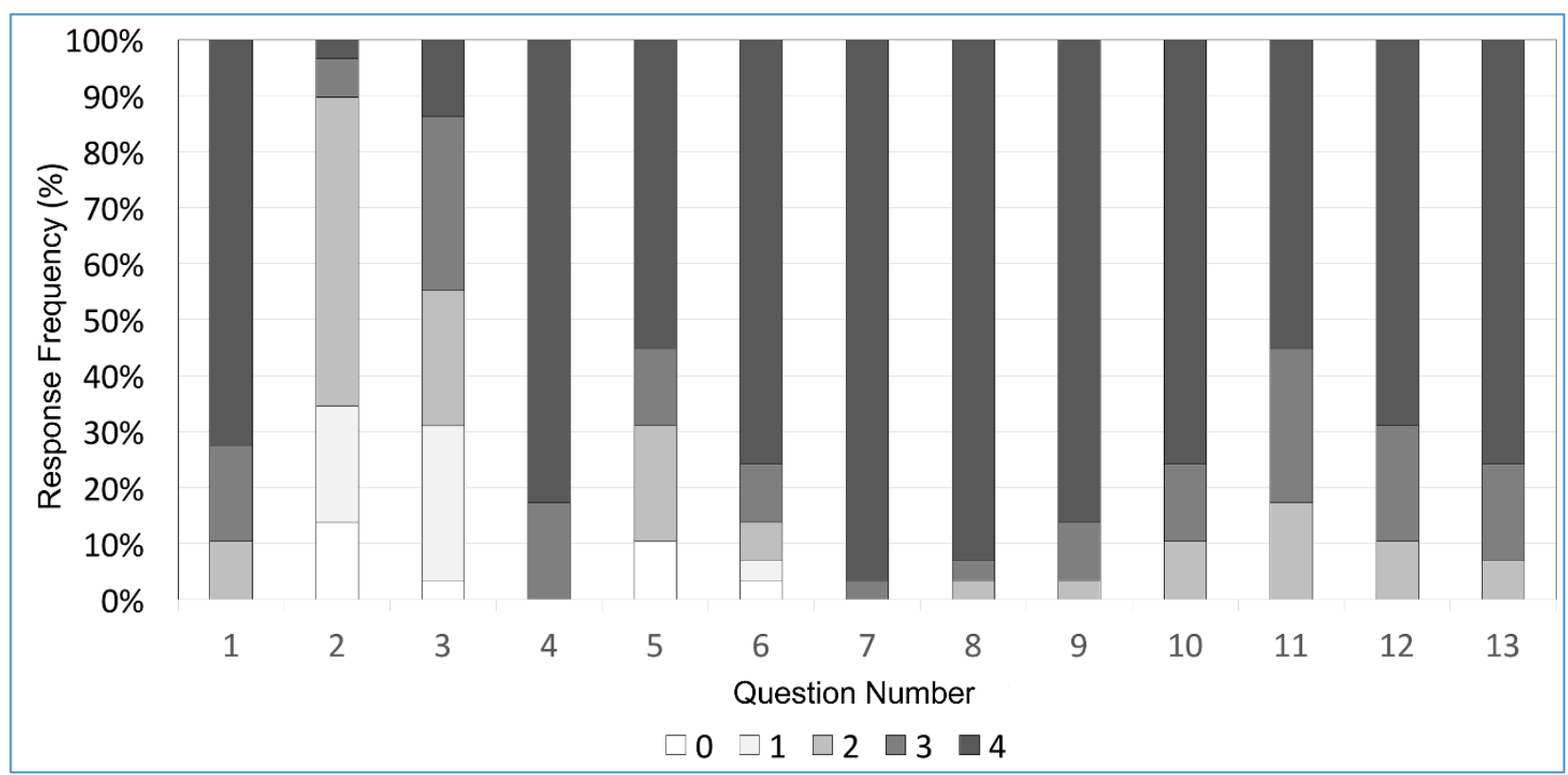

Figure 3 - Answers frequency according to each question on the assessment questionnaire of the VLO.

\section{DISCUSSION}

Using the object in a VLE was effective and allowed online access to all of the participants. Accessibility of VLOs must be planned prior to the development of a distance course. It is important to consider whether this educational object will be available for all operating systems, for both computers and mobile devices. Authors want to be able to export heir VLOs to HTML5 language, which is compatible with the vast majority of devices. However, this demands a substantial initial investment ${ }^{5}$. Articulate software also demands financial investment, but manages to meet the needs of the project because it offers applications for Android and iOS platforms, in addition to being compatible with LMS platforms, such as Moodle, and HTML5 platforms, such as web browsers.

Previous studies have already described the development of educational objects. However, the influence of these objects on the learning process must also be assessed. This study included the development of a $2 \mathrm{D}$ virtual simulator, but 3D simulation has an advantage over $2 \mathrm{D}$ simulation when it comes to helping students in their learning process $^{16}$, especially in terms of users' spatial ability in laboratory procedures ${ }^{17}$. That is why a $3 \mathrm{D}$ virtual simulator of the manipulation of ZPC should be chosen to assess the amount of knowledge Dentistry students have gained and their manipulation ability.

The so-called "serious games" have 
become prominent both in training, advertisements, simulations ${ }^{18}$ and in higher education. Gamification techniques in virtual simulators are used mainly in areas in which this kind of technology is needed for professional development ${ }^{19}$.

One of the strengths about producing VLOs is the possibility to make use of these objects simultaneously in many different locations, thereby improving Dentistry teaching on a large scale, saving time, and reaching people in geographically remote regions. In order to obtain a high level of learning, some online educational objects demand study time from students similar to that of traditional teaching methods ${ }^{6}$. This leads to the development of materials, which are at least close to conservative approaches.

Guidelines to access the quality of VLO are not always a consensus, since there is a great variability of outcomes that each VLO aim. This study utilized an adaptation of a preexistent guideline ${ }^{15}$. Most of the answers were 3 or 4 points at scale, which means that students presented a great acceptance of the VLO. However, questions 2 and 3 showed less points, which could be explained by the fact that the meaning of the original question was the opposite, which might have led to a false negative.

Despite the fact that the adaptation of the instrument was to increase the level of internal consistency of the questionnaire (Cronbach's coefficient alpha), our study presented a 0.57 value from a desirable 0.7-1.0 range. On the other hand, even when with the low internal consistency, the practical performance of students manipulating ZPC increased when evaluated with a randomized controlled trial with increased knowledge retention ${ }^{20}$.

\section{CONCLUSIONS}

Planning a course on luting agents focusing on ZPC showed to be an appropriate tool that can serve as a guide to develop a VLO. Articulate software was effective in joining all of the media (audios, images, videos, and the virtual simulation task) into one single without bringing any harm to the VLO interface. The development of an interactive VLO with media tools on ZPC was highly approved by dental students.

\section{REFERENCES}

1. Harden RM, Hart IR. An international virtual medical school (IVIMEDS): The future for medical education? Med Teach 2002;24(3):261-7.

2. Machado M, Tao E, editors. Blackboard vs. Moodle: Comparing user experience of learning management systems. FIE; 2007. Available at: http://ieeexplore.ieee. org/xpl/ login.jsp?tp=\&arnumber $=4417910 \& u r l=h t t$ p\%3A\%2F\%2Fieeexplore.ieee.org\%2Fstam p\%2Fstamp.jsp\%3Ftp\%3D\%26arnumber\% $\underline{\text { 3D4417910 }}$

3. Cook DA, Levinson AJ, Garside S. Time and learning efficiency in Internet-based learning: A systematic review and metaanalysis. Adv Health Sci Educ 2010; 15(5):755-70.

4. Hansen MM. Versatile, immersive, creative and dynamic virtual 3-D healthcare learning environments: A review of the literature. $\mathrm{J}$ Med Internet Res 2008;10(3):e26. Available at: http://www.ncbi.nlm.nih.gov/pmc/arti cles/PMC2626432/

5. Rendeiro MIdCdSM, Jorge RR, Maia KD, Monnerat ABL, Ritto MRdS. Utilização do ensino à distância como ferramenta de capacitação e formação para técnico em saúde bucal. Rev ABENO. 2013;13(2):2733. 
6. Alquati Bisol C, Valentini CB, Rech Braun KC. Teacher education for inclusion: Can a virtual learning object help? Comput Educ 2015;85(0):203-10.

7. Gamberini L, Chittaro L, Spagnolli A, Carlesso C. Psychological response to an emergency in virtual reality: Effects of victim ethnicity and emergency type on helping behavior and navigation. Comput Human Behav 2015;48(0):104-13.

8. Stanney KM, Cohn JV. Virtual Environments. Handbook of Human Factors and Ergonomics: 4ed 2012. p. 1031-56.

9. Stapleton AJ. Serious Games: Serious Opportunities. Australian Game Developers' Conference. 2004:1-6.

10. de Boer IR, Lagerweij MD, Wesselink PR, Vervoorn JM. Evaluation of the appreciation of virtual teeth with and without pathology.

Eur J Dent Educ 2015;19(2):87-94.

11. De Boer IR, Wesselink PR, Vervoorn JM. The creation of virtual teeth with and without tooth pathology for a virtual learning environment in dental education. Eur J Dent Educ 2013;17(4):191-7.

12. Noort RV. The introduction to dental materials. 3 ed. St. Louis : Elsevier, 2010.

13. Anusavice; KJ, Shen; C, Rawls HR. Philip's Science of Dental Materials. 12 ed. St. Louis : Elsevier/Saunders, c2013.; 2012. 571 p.

14. Bohn PV, Andrioli D, Leitune VCB, Collares FM, Botega DM, Meira D, et al. Cimentos Usados em Prótese Fixa: uma pesquisa com especialistas em prótese de Porto Alegre. Rev Fac Odontol 2009;50(3):5-9.

15. Reategui E, Boff E, Finco MD. Proposta de Diretrizes para Avaliação de Objetos de Aprendizagem Considerando Aspectos Pedagógicos e Técnicos. RENOTE. 2010;8(3). Available at: http://seer. ufrgs.br/index.php/renote/article/view/1806 6/10653

16. Remmele $\mathrm{M}$, Weiers $\mathrm{K}$, Martens $\mathrm{A}$. Stereoscopic 3D's impact on constructing spatial hands-on representations. Comput Educ 2015;85:74-83.
17. Lee EA-L, Wong KW. Learning with desktop virtual reality: Low spatial ability learners are more positively affected. Comput Educ 2014;79(0):49-58.

18. Susi T, Johannesson M, Backlund P. Serious Games - An Overview. Technical Report University of Skövde, Sweden. 2007:1-24.

19. Williams-Bell FM, Kapralos B, Hogue A, Murphy BM, Weckman EJ. Using Serious Games and Virtual Simulation for Training in the Fire Service: A Review. Fire Technol 2015;51(3):553-84.

20. Tubelo RA, Leitune VCB, Dahmer A, Samuel SMW, Collares FM. The influence of a learning object with virtual simulation for dentistry: a randomized controlled trial. Int $\mathbf{J}$ Med Inform 2016;85(1):68-75.

\section{RESUMO}

\section{Desenvolvimento e avaliação de um objeto} virtual de aprendizagem com simulação virtual sobre cimento de fosfato de zinco

O objetivo do estudo foi desenvolver e avaliar um objeto virtual de aprendizagem (OVA) sobre o tema "agentes de cimentação", com ênfase no cimento de fosfato de zinco (CFZ). A metodologia e as ferramentas necessárias para o desenvolvimento do OVA são descritas. Estudantes de graduação $(n=29)$ utilizaram o objeto durante 15 dias e, para avaliarem-no, responderam a um questionário sobre os aspectos técnicos e pedagógicos do objeto usando uma escala de 4 pontos. $\mathrm{O}$ desenvolvimento do objeto permitiu a criação de uma simulação virtual da manipulação do CFZ. O objeto foi bem avaliado pelos estudantes (4 pontos, 65,78\%; 3 pontos, $14,85 \%$ ) estudantes. O software utilizado foi capaz de reunir todas as mídias em um OVA com alta taxa de aprovação entre os estudantes de Odontologia. 
Descritores: Materiais Dentários. Educação a

Distância. Simulação por Computador.

Correspondência para

Prof. Dr. Fabrício Mezzomo Collares

e-mail: fabricio.collares@ufrgs.br

Faculdade de Odontologia da UFRGS

Laboratório de Materiais Dentários

Rua Ramiro Barcelos 2492 - Santana

90035-003 Porto Alegre, RS 